\title{
One-Pot Reaction Involving Three Different Amines and Formaldehyde Leading to the Formation of New Hexaaza Macrobicyclic Copper(II) Complexes
}

\author{
Shin-Geol Kang- and Young Hun Lee \\ Deparment of Chemistry, Daegu Chiversitw, Gveongsan 712-714. Korea. E-mail: sgkangtodaeguac.kr \\ Received April 2, 2009, Accepted Hav 21, 2009
}

Key Wonds: Template synthesis. Macrocyclic complexes. One-pot reaction. Copper(II) complexes

Multi-component reactions. which generally mean one-pot processes imvolving several easily accessible reagents to produce a single product. have become an important area in modern sy nthetic chemistry. ${ }^{1-19}$ Especially. multi-component reactions involving metal ion amines. and formaldehyde have been utilized for the preparation of polyaza macrocyclic and macropolycyclic complexes containing $\mathrm{N}-\mathrm{CH}_{2}-\mathrm{N}$ linkages. ${ }^{2 \cdot 1 \mathrm{c}}$ For instance, the 1+-membered hexaaza macrotricyclic complexes $[\mathrm{M}(\mathbf{2})]^{2+}(\mathrm{M}=\mathrm{Cu}(\mathrm{II})$ or $\mathrm{Ni}(\mathrm{II}))$ containing two 1,3-diazacyclopentane rings have been prepared by the reaction $(\mathrm{Eq}$. (I)) of formaldehyde with one kind of triamine (diethylenetriamine) in the presence of the metal ion. ${ }^{5}$ Recently, the 15-membered hexaaza macrotricyclic complexes $[\mathrm{Cu}(3)]^{\hat{-}}$ and $[\mathrm{Cu}(4)]^{2+}$ have been also prepared by the reaction (Eq. (2) or (3)) of formaldehyde with two different amines. ${ }^{6,7}$ It has been revealed that such one-pot metal-template condensation reactions are useful routes toward various types of polyaza macrocyclic complexes that could not be synthesized by other methods. ${ }^{3-110}$ In most cases, however. formaldehyde reacts with only one or two kinds of amine species.

There has been minimal research on the one-pot metaltemplate condensations involving three different amines or more. ${ }^{9}$ To the best of our knowledge. $[\mathrm{M}(6)]^{++}$(Cu(II) or $\mathrm{Ni}(\mathrm{II})$ ) is a rare example that prepared from the reaction of three different amines with formaldehy'de. ${ }^{9}$ Although $[\mathrm{M}(6)]^{{ }^{-}}$ bearing one $\mathrm{H}$-Me group is prepared by the reaction (Eq. (4)) of formaldehyde with diethylenetriamine. ethylenediamine. and methylamine in the presence of the metal ion, it is formed at best in low yield $(-10 \%)$ because of competing reactions. such as Eqs. (1) and (5). Furthermore the preparation of other hexaaza macrobicyclic complexes containing bulkier pendant arm. such as $\mathrm{N}-\mathrm{CH}_{2} \mathrm{CH}_{3}$ or $\mathrm{N}-\mathrm{CH}_{2} \mathrm{CH}_{2} \mathrm{CH}_{3}$ group. could not be achieved; $[\mathrm{M}(2)]^{2+}$ was prepared as the major product when ethylamine or $n$-propylamine was reacted instead of methylamine.

It has been reported that 15 -membered hexaaza macrocyclic copper(II) complexes with a 5-6-6-6 chelate ring sequence. such as $[\mathrm{Cu}(3)]^{3+}$. $[\mathrm{Cu}(4)]^{2+}$. and $[\mathrm{Cu}(5)]^{2+}$. are readily decomposed in low $\mathrm{pH}$. unlike the 14 -membered macrocyclic complexes $[\mathrm{Cu}(2)]^{++}$and $[\mathrm{Cu}(6)]^{--6^{*}}$ Interestingly. their decomposition reaction rates are strongly influenced by the ligand stnicture. For instance the reaction rate ratios for $[\mathrm{Cu}(5)]^{2^{-}}:[\mathrm{Cu}(3)]^{2-}:[\mathrm{Cu}(4)]^{++}$in $0.3 \mathrm{M} \mathrm{HClO}_{4}$ solution are approximately $1: 10^{-}: 10^{4}$. However the reasons for such kinetic behaviors have not been thoroughly investigated. since examples of 15-membered hexaaza macrocyclic

complexes with a 5-6-6-6 chelate ring sequence are limited in number. Therefore, we have been interested in the preparation of various types of 15-membered hexaaza macrocyclic complexes with a 5-6-6-6 chelate ring sequence.

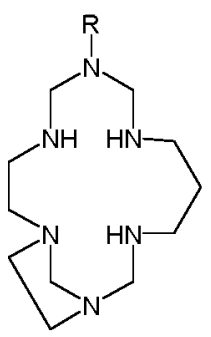

1a: $\mathrm{R}=\mathrm{CH}_{3}$

1b: $\mathrm{R}=\mathrm{CH}_{2} \mathrm{CH}$

lc: $\mathrm{R}=\mathrm{CH}_{2} \mathrm{CH}_{2} \mathrm{CH}_{3}$

1d: $\mathrm{R}=\mathrm{CH}_{2} \mathrm{C}_{6} \mathrm{H}_{3}$

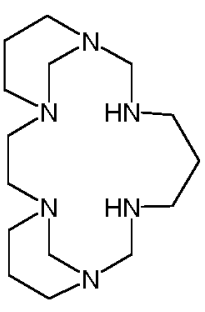

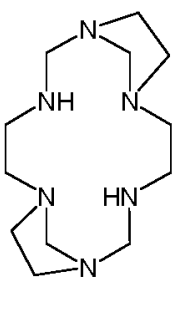

2

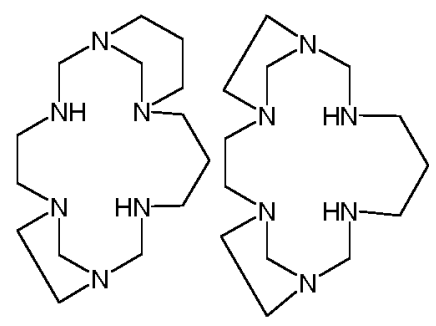

3

4

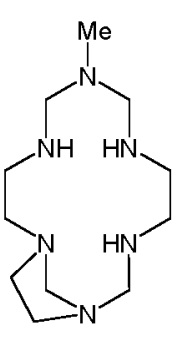

6

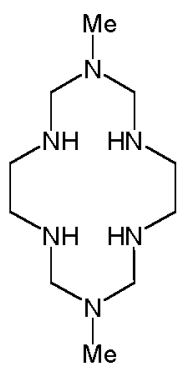

7

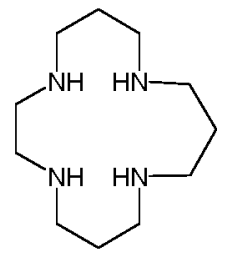

$$
\begin{aligned}
& \mathrm{M}^{2-}+2 \mathrm{H}_{2} \mathrm{~N}\left(\mathrm{CH}_{2}\right)_{2} \mathrm{NH}\left(\mathrm{CH}_{2}\right]_{2} \mathrm{NH}_{2}+4 \mathrm{HCHO} \rightarrow[\mathrm{M}(2)]^{2+} \\
&(\mathrm{M}=\mathrm{Ni} \text { or } \mathrm{Cu})(1)
\end{aligned}
$$

$\mathrm{Cu}^{2-}+\mathrm{H}_{2} \mathrm{~N}\left(\mathrm{CH}_{2}\right)_{2} \mathrm{NH}\left(\mathrm{CH}_{2}\right)_{2} \mathrm{NH}_{2}+\mathrm{H}_{2} \mathrm{~N}\left(\mathrm{CH}_{2}\right)_{3} \mathrm{NH}\left(\mathrm{CH}_{2}\right)_{3} \mathrm{NH}_{2}$

$+4 \mathrm{HCHO} \rightarrow[\mathrm{Cu}(3)]^{2-}$

$\mathrm{Cul}^{2-}+\mathrm{H}_{2} \mathrm{~N}\left(\mathrm{CH}_{2}\right)_{2} \mathrm{NH}\left(\mathrm{CH}_{2}\right)_{2} \mathrm{NH}\left(\mathrm{CH}_{2}\right)_{2} \mathrm{NH}_{2}+\mathrm{H}_{2} \mathrm{~N}\left(\mathrm{CH}_{2}\right)_{3} \mathrm{NH}_{2}$

$+4 \mathrm{HCHO} \rightarrow[\mathrm{Cu}(4)]^{2+}$

$\left.\mathrm{M}^{2-}+\mathrm{H}_{2} \mathrm{~N}\left(\mathrm{CH}_{2}\right)_{2} \mathrm{NH}\left(\mathrm{CH}_{2}\right)_{2} \mathrm{NH}_{2}+\mathrm{H}_{2} \mathrm{~N}_{(} \mathrm{CC}_{2}\right)_{2} \mathrm{NH}_{2}+\mathrm{CH}_{3} \mathrm{NH}_{2}$

$+4 \mathrm{HCHO} \rightarrow[\mathrm{M}(6)]^{2-}$ $(\mathrm{M}=\mathrm{Ni}$ or $\mathrm{Cu})(4)$

$\mathrm{M}^{2^{-}}+2 \mathrm{H}_{2} \mathrm{~N}\left(\mathrm{CH}_{2}\right)_{2} \mathrm{NH}_{2}+2 \mathrm{CH}_{3} \mathrm{NH}_{2}+4 \mathrm{HCHO} \rightarrow\left[\mathrm{M}(7 \mathrm{j}]^{2^{-}}\right.$ $(\mathrm{M}=\mathrm{Ni}$ or $\mathrm{Cll})(5)$

$\mathrm{Cu}^{2-}+\mathrm{H}_{2} \mathrm{~N}\left(\mathrm{CH}_{2}\right)_{2} \mathrm{NH}\left(\mathrm{CH}_{2}\right)_{2} \mathrm{NH}_{2}+\mathrm{H}_{2} \mathrm{~N}\left(\mathrm{CH}_{2}\right)_{3} \mathrm{NH}_{2}+\mathrm{R}-\mathrm{NH}_{2}$

$+4 \mathrm{HCHO} \rightarrow[\mathrm{Cu}(\mathrm{L})]^{1+}$

$(\mathrm{L}=1 \mathrm{a}, 1 \mathrm{~b}, 1 \mathrm{c}$, or $1 \mathrm{~d})(6)$

$\left(\mathrm{R}=\mathrm{CH}_{3}\right.$ for $1 \mathrm{a}, \mathrm{CH}_{2} \mathrm{CH}_{3}$ for $1 \mathrm{~b}, \mathrm{CH}_{2} \mathrm{CH}_{2} \mathrm{CH}_{3}$ for $1 \mathbf{c}$, and $\mathrm{CH}_{2} \mathrm{C}_{6} \mathrm{H}_{3}$ for $1 d$ ) 
In this work, we examined one-pot metal-template condensation (Eq.(6)) of three different amines with formaldehyde under various experimental conditions and successfully prepared new 15 -membered hexaaza macrobicyclic complexes $[\mathrm{Cu}(\mathbf{L})]^{--}(\mathrm{L}=\mathbf{1 a}$. 1b. 1c. or 1d) with a 5-6-6-6 chelate ring sequence in high yield. Selective preparation and characterization of the copper(II) complexes are reported.

\section{Experimental Section}

Measurements. Infrared spectra were recorded with a Shimadzu IR-4t0 spectrophotometer. electronic absorption spectra with an Analytikjena Specord 200 UV/Vis spectrophotometer and conductance measurements with a Metrohm Herisaul Conductometer E518. FAB-mass spectra were performed at the Korea Basic Science Institute. Daegu, Korea. Elemental Analyzes were performed at the Research Center for Instrumental Analysis. Daegu University. Korea.

Safety Note: Perchlorate salts of transition metal complexes with organic ligands are often explosive and should be handled with caution.

Preparation of $[\mathrm{Cu}(1 \mathrm{a})]\left(\mathrm{ClO}_{4}\right)_{2}(1 \mathrm{a}=9$-methyl-1,3,7,9,11,14hexaazabicyclo[12.2.1] heptadecane). To a methanol solution $(c a .40 \mathrm{~mL})$ of $\mathrm{Cu}(\mathrm{OAc})_{2} \mathrm{H}_{2} \mathrm{O}(+.0 \mathrm{~g} .20 \mathrm{mmol})$ were added $99 \% 1.3$-diaminopropane ( $1.9 \mathrm{~mL} .22 \mathrm{mmol}) .97 \%$ diethylenetriamine $(2.0 \mathrm{~mL}, 18 \mathrm{mmol})$, and $40 \%$ methylamine $(2.2$ $\mathrm{mL} .22 \mathrm{mmol})$. The solution was stirred in a cold water bath $(<$ $\left.15{ }^{\circ} \mathrm{C}\right)$ for $\mathrm{ca} .30 \mathrm{~min}$, and $35 \%$ formaldelyde $(9.4 \mathrm{~mL} .120$ mmol) was added to the cold solution. The resulting blue solution was stirred at $40-50^{\circ} \mathrm{C}$ for $20 \mathrm{~h}$. After the addition of an excess amount of $\mathrm{NaClO}_{+}$, the mixture was stored at room temperature to produce a purple solid. The crude product often contains a small amount $(<10 \%)$ of $[\mathrm{Cu}(2)]\left(\mathrm{ClO}_{4}\right)=$ as a by-product. The product was collected by filtration and recrystallized from hot water. Yield: $4.5 \mathrm{~g}$ ( $\mathrm{ca} .50 \%$ ). Anal. Found: C. 27.75: $\mathrm{H} .5 .50: \mathrm{N}$. 16.11. Calc. for $\mathrm{C}_{13} \mathrm{H}_{38} \mathrm{~N}_{6} \mathrm{CuCl}_{2} \mathrm{O}_{8}$ : C, 27.78: H, 5.44: N. $16.20 \%$. FAB mass $(m / z): 418.1$ for $\left[\mathrm{Cu}(\mathbf{1 a})+\mathrm{ClO}_{4}\right]^{-}: 319.1$ for $[\mathrm{Cu}(\mathbf{1 a})-\mathrm{H}]^{-}$. IR (Nujol mull. $\left.\mathrm{cm}^{-1}\right): 3253\left(v_{-\mathrm{H}}\right) .3222\left(v_{\mathrm{N} \cdot \mathrm{H},}, b r\right)$.

Preparation of $[\mathrm{Cu}(1 \mathrm{~b})]\left(\mathrm{ClO}_{4}\right)_{2}(1 \mathrm{~b}=9$-ethyl-1,3,7,9,11,14 hexaazabicyclo[12.2.1] heptadecane). This complex was prepared by a method similar to that for $[\mathrm{Cu}(\mathbf{1 a})]\left(\mathrm{ClO}_{4}\right)$ _. except that $70 \%$ ethylamine $(2.2 \mathrm{~mL} .22 \mathrm{mmol}$ ) was used instead of methylamine. Yield: $4.7 \mathrm{~g}(\mathrm{ca} .50 \%)$. Anal. Found: C, 29.24; H, 5.55: N, 15.70. Calc. for $\mathrm{C}_{13} \mathrm{H}_{3(1} \mathrm{N}_{6} \mathrm{CuCl}_{2} \mathrm{O}_{8}:$ C. 29.30: $\mathrm{H}$. 5.67: N. $15.77 \%$. FAB mass $(m / z): 432.1$ for $[\mathrm{Cu}(1 \mathrm{~b})+$ $\left.\mathrm{ClO}_{4}\right]^{-}: 333.1$ for $[\mathrm{Cu}(\mathbf{1 b})-\mathrm{H}]^{+}$. IR (Nujol mull. $\left.\mathrm{cm}^{-1}\right): 3256$ $\left(\mathrm{v}_{\mathrm{N}: \mathrm{H}}\right) .3247\left(\mathrm{v}_{\mathrm{N} \cdot \mathrm{H}}\right) .3203\left(\mathrm{v}_{\mathrm{N} \cdot \mathrm{H}}\right)$.

Preparation of $[\mathrm{Cu}(1 \mathrm{c})]\left(\mathrm{ClO}_{4}\right)_{2}(1 \mathrm{c}=9-(n-\mathrm{propy}])-1,3,7,9$, 11,14-hexaazabicyclo[12.2.1] heptadecane). This complex was prepared by a method similar to that for $[\mathrm{Cu}(\mathbf{1 a})]\left(\mathrm{ClO}_{4}\right)_{2}$. except that $99 \% n$-propylamine ( $2.2 \mathrm{~mL}, 22 \mathrm{mmol}$ ) was used instead of methylamine. This compound was recrystallized from hot water-acetonitrile (1:1). Yield $4.9 \mathrm{~g}(\mathrm{ca} .50 \%)$. Anal. Found: C. 30.57: $\mathrm{H}, 5.84: \mathrm{N}$. 15.24. Calc for $\mathrm{C}_{14} \mathrm{H}_{3} \mathrm{~N}_{6} \mathrm{CuCl}_{2} \mathrm{O}_{8}$ : C, 30.75: H, 5.90: N. $15.37 \%$. FAB mass $(m / z): 446.1$ for $\left[\mathrm{Cu}(1 \mathrm{c})+\mathrm{ClO}_{4}\right]^{-}: 347.2$ for $[\mathrm{Cu}(1 \mathrm{c})-\mathrm{H}]^{-}$. IR (Nujol mull. $\left.\mathrm{cm}^{-1}\right): 3246\left(v_{\mathrm{N} \cdot \mathrm{H}}\right) .3210\left(v_{\mathrm{N} \cdot \mathrm{H},}, b r\right)$.
Preparation of $[\mathrm{Cu}(\mathbf{1 d})]\left(\mathrm{ClO}_{4}\right)_{2}(\mathrm{dd}=9$-(phenylmethy $)$ $1,3,7,9,11,1+$-hexaazabicyclo[12.2.1] heptadecane). This complex was prepared by a method similar to that for $[\mathrm{Cu}(\mathbf{1 a})]$ $\left(\mathrm{ClO}_{4}\right)_{2}$, except that $99 \%$ benzylamine $(2.88 \mathrm{~mL}, 22 \mathrm{mmol})$ was used instead of methylamine. This compound was recrystallized from hot water-acetonitrile (1:2). Yield: $6.2 \mathrm{~g}(\mathrm{ca}$. 60\%). Anal. Found: C. 36.14: H. 5.68: N. 14.30. Calc. for $\mathrm{C}_{18} \mathrm{H}_{32} \mathrm{~N}_{6} \mathrm{CuCl}_{2} \mathrm{O}_{3}$ : C. 36.34 : H. 5.42: N, $14.13 \%$. FAB mass $(m / z): 494.1$ for $\left[\mathrm{Cu}(\mathbf{1 d})+\mathrm{ClO}_{4}\right]^{+} ; 395.2$ for $[\mathrm{Cu}(\mathbf{1 d})-\mathrm{H}]^{-}$. IR (Nujol mull. cm $\left.{ }^{-1}\right): 3249\left(v_{\mathrm{N} \cdot \mathrm{H}}\right) .3231\left(v_{\mathrm{N} \cdot \mathrm{H}}, b r\right) .3050\left(v_{\mathrm{CH} . \mathrm{H}}\right.$ phenyl $), 1630\left(v_{c}=\right.$, phenyl).

\section{Results and Discussion}

Synthesis. Initial attempts to prepare $[\mathrm{Cu}(\mathbf{1 a})]\left(\mathrm{ClO}_{4}\right)_{2}$ from the reaction (Eq. (6)) of formaldelyde with a $1: 1: 1: 1$ molar mixture of $\mathrm{Cu}\left(\mathrm{OAC}_{2} \cdot \mathrm{H}_{2} \mathrm{O}\right.$. diethy lenetriamine, 1.3-propanediamine, and methylanine in boiling methanol were not quite successfil because of the competing reaction (Eq. (1)) involving diethylenetriamine and formaldehyde: the major product obtained by the addition of $\mathrm{NaClO}_{4}$ to the reaction solution was $[\mathrm{Cu}(2)]\left(\mathrm{ClO}_{4}\right)_{2}$. A similar result was also observed in the attempts at room temperature. As described in the Experimental Section. however. $[\mathrm{Cu}(1 \mathrm{a})]\left(\mathrm{ClO}_{4}\right)_{2}$ could be prepared in high yield $(-50 \%)$ by the careful control of the reaction conditions: the temperature of the solution was maintained at $\leq 15^{\circ} \mathrm{C}$ during the addition of formaldehyde and then the resulting reaction nixture was stirred at $40-50^{\circ} \mathrm{C}$. Although the crude product often contains relatively small amount $(<$ $10 \%$ ) of $[\mathrm{Cu}(2)]\left(\mathrm{ClO}_{4}\right)_{2}$ as a by-product, $[\mathrm{Cu}(\mathbf{1 a})]\left(\mathrm{ClO}_{4}\right)=\mathrm{can}$ be isolated readily by the fractional recystallizations of the product. The copper(II) complexes of $\mathbf{1 b} \mathbf{- 1} \mathbf{d}$ bearing bulkier $\mathrm{N}$-alkyl pendant arm was also prepared as the major products (vield: $50-60 \%$ ) by reacting appropriate primary alkylamine (ethylamine. $n$-propylamine. or benzyl anine) instead of methylamine.

All our efforts to prepare nickel(II) complexes of 1a - 1d from the similar one-pot reaction in the presence of nickel(II) ion were unsuccessful. The only macrocyclic complex obtained from each attempt was $[\mathrm{Ni}(2)]\left(\mathrm{ClO}_{4}\right)_{2}$. The present result is different from the fact that $[\mathrm{Ni}(6)]^{3^{+}}$can be prepared from the reaction of Eq. (4). This may be intimately linked with the trend that polyaza macrocyclic complexes with a 5-6-6-6 chelate ring sequence are much less stable than those with a 5-6-5-6 chelate ring sequence. ${ }^{6.711 .12}$ The formation of the copper(II) complexes of 1a - 1d with a 5-6-6-6 chelate ring sequence implicates that the metal ion. which is stronger Lewis acid than $\mathrm{Ni}^{2+}$ ion stabilizes the coordinated secondary anino groups involved in the $\mathrm{N}-\mathrm{CH}_{2}=\mathrm{N}$ linkages of the complexes. ${ }^{6 / 2}$ It should be pointed out that the yield $(50-60 \%)$ of the copper(II) complexes of 1a - 1d is considerably higher than that reported for $[\mathrm{Cu}(6)]\left(\mathrm{ClO}_{4}\right) \approx(10 \%)$, which has been prepared from the reaction of Eq. $(4){ }^{9}$

Spectra and Properties. Unfortunately. we could not obtain single crystals of $[\mathrm{Cu}(\mathrm{L})]\left(\mathrm{ClO}_{4}\right)_{2}(\mathrm{~L}=1 \mathbf{a}$. 1b. 1c. or 1d) suitable for X-ray crystallography. However, the formation of the complexes could be confirmed by their FAB mass and infrared spectra as well as the elemental analyses (see Experimental 
Table 1. Electronic Absorption Spectra of the complexes

\begin{tabular}{|c|c|c|c|c|}
\hline Complex & \multicolumn{4}{|c|}{$\lambda_{\text {max }}, \operatorname{nin}\left(\varepsilon, \mathrm{M}^{-1} \mathrm{~cm}^{-1}\right)^{a}$} \\
\hline$[\mathrm{Cu}(1 \mathrm{a})]\left(\mathrm{ClO}_{4}\right)_{2}$ & $532(148)$ & $543(1+2)^{4}$ & $544(165)^{c}$ & $540^{27}$ \\
\hline$[\mathrm{Cu}(1 \mathrm{~b})]\left(\mathrm{ClO}_{4}\right)_{2}$ & $533(155)$ & $545(143)^{4}$ & $543(170)^{6}$ & $530^{67}$ \\
\hline$[\mathrm{Cu}(1 \mathrm{c})]\left(\mathrm{ClO}_{4}\right)_{2}$ & $530(151)$ & $544(147)^{h}$ & $546(146)^{c}$ & $540^{67}$ \\
\hline$[\mathrm{Cu}(1 \mathrm{~d})]\left(\mathrm{ClO}_{4}\right)_{2}$ & $530(147)$ & $344(147)^{4}$ & $545(156)^{c}$ & $535^{67}$ \\
\hline$[\mathrm{Cu}(3)]\left(\mathrm{ClO}_{4}\right) \mathrm{e}^{\circ}$ & $566(235)$ & $574(196)^{b}$ & $596(210)^{c}$ & \\
\hline$[\mathrm{Cu}(4)]\left(\mathrm{ClO}_{4}\right) \mathrm{f}^{f}$ & $553(175)$ & $555(173)^{b}$ & $555(150)^{r}$ & \\
\hline$[\mathrm{Cu}(6)]\left(\mathrm{ClO}_{4}\right)_{2}{ }^{\mathrm{g}}$ & $490(102)$ & $506(109)^{b}$ & $502(113)^{c}$ & \\
\hline
\end{tabular}

"Measured in nitromethane at $20{ }^{\circ} \mathrm{C}$ unless otherwise specified. ${ }^{b} \mathrm{In}$ acetonitrile. 'In water. "In Nujol mull. 'Ref. 6. ${ }^{\prime}$ Ref. $7 .{ }^{\text {g }}$ Ref.' 9

Section). In the FAB mass spectra of the complexes. two groups of peaks corresponding to the fragments $\left[\mathrm{Cu}(\mathrm{L})+\mathrm{ClO}_{4}\right]^{+}$and $[\mathrm{Cu}(\mathrm{L})-\mathrm{H}]^{-}$are observed. The infrared spectra of the complexes show $\mathrm{v} \cdot \mathrm{H}$ of the coordinated secondary amino groups at $c a$. $3200 \mathrm{~cm}^{-1}$. The molar conductance values of the complexes measured in water $\left(210-230 \Omega^{-1} \mathrm{~mol}^{-1} \mathrm{~cm}^{2}\right)$ and acetonitrile $\left(240-260 \Omega^{\cdot 1} \mathrm{~mol}^{-1} \mathrm{~cm}^{2}\right)$ show that they are $1: 2$ electrolytes. In the electronic absorption spectnum (Table 3 ) of $[\mathrm{Cu}(\mathbf{1 a})]\left(\mathrm{ClO}_{4}\right)_{2}$ measured in nitromethane. a $d-d$ transition band is observed at $532 \mathrm{~nm}\left(\varepsilon=148 \mathrm{M}^{-3} \mathrm{~cm}^{-1}\right)$. The spectra of $[\mathrm{Cu}(1 \mathrm{~b})]\left(\mathrm{ClO}_{4}\right)_{2}$. $[\mathrm{Cu}(1 \mathrm{c})]\left(\mathrm{ClO}_{4}\right)_{2}$, and $[\mathrm{Cu}(\mathbf{1 d})]\left(\mathrm{ClO}_{4}\right)_{2}$ are quite similar to that of $[\mathrm{Cu}(1 \mathrm{a})]\left(\mathrm{ClO}_{4}\right)_{-}$, showing that their ligand field strengths or Cll-N interactions are not affected significantly by the nature of the $N$-alkyl groups. The spectra of the copper(II) complexes of 1a - 1d are comparable with those of other square-planar copper(II) complexes with a 5-6-6-6 chelate ring sequence. such as $[\mathrm{Cu}(3)]\left(\mathrm{ClO}_{4}\right)_{2}$ and $[\mathrm{Cu}(4)]\left(\mathrm{ClO}_{4}\right)_{2}$. ${ }^{6,7}$ However, the wavelengths for the complexes of 1a-1d are $20-36 \mathrm{~nm}$ shorter than those for $[\mathrm{Cu}(3)]\left(\mathrm{ClO}_{4}\right)_{2}$ and $[\mathrm{Cu}(4)]\left(\mathrm{ClO}_{4}\right)_{2}$ containing two coordinated tertiary amino groups. indicating that the former complexes exhibit stronger ligand field strength than the latter ones. This trend corresponds to the general observation that the stepwise alkylation on the coordinated secondary amino groups of a polyaza macrocyclic copper(II) complex weakens the $\mathrm{Cu}-\mathrm{N}$ interactions. The wavelengths for the copper(II) complexes of $\mathbf{1 a - 1 d}$ are ca. 40 num longer than that for $[\mathrm{Cu}(6)]\left(\mathrm{ClO}_{4}\right)_{2}$. This is attributed to the relatively large

Table 2. Decomposition Rate Constants ( $\left.k_{\text {nbs }}\right)$ of the Complexes in $0.3 \mathrm{M} \mathrm{HClO}_{4}$ Solutions at $20^{\circ} \mathrm{C}^{4}$

\begin{tabular}{|c|c|}
\hline Complex & $k_{\text {nbsid, }} s^{-1}$ \\
\hline$[\mathrm{Cu}(1 \mathrm{a})]\left(\mathrm{ClO}_{4}\right)_{2}$ & $2.9 \times 10^{.5}(c a .6 .6 \mathrm{~h})$ \\
\hline$[\mathrm{Cu}(1 \mathrm{~b})]\left(\mathrm{ClO}_{4}\right)_{2}$ & $9.4 \times 10^{.5}(c a .20 .5 \mathrm{~h})$ \\
\hline$[\mathrm{Cu}(1 \mathrm{c})]\left(\mathrm{ClO}_{4}\right)_{2}$ & $5.4 \times 10^{.5}(c a .35 .5 \mathrm{~h})$ \\
\hline$[\mathrm{Cu}(1 \mathrm{~d})]\left(\mathrm{ClO}_{4}\right)_{2}$ & $2.1 \times 10^{-6}(c a .91 .6 \mathrm{~h})$ \\
\hline$[\mathrm{Cu}(3)]\left(\mathrm{ClO}_{4}\right):^{b}$ & $1.2 \times 10^{-4}(\mathrm{cod} .1 .5 \mathrm{~h})$ \\
\hline$[\mathrm{Cul}(4)]\left(\mathrm{ClO}_{4}\right)_{2}{ }^{c}$ & $1.4 \times 10^{-\hat{*}}(\mathrm{cor} .50 \mathrm{sec})$ \\
\hline$[\mathrm{Cu}(6)]\left(\mathrm{ClO}_{4}\right)_{2}^{d}$ & very slow \\
\hline$[\mathrm{Cu}(8)]^{2-\ell}$ & $3.3 \times 10^{-3}(c a .210 \mathrm{sec})$ \\
\hline
\end{tabular}

${ }^{a}[$ Complex $]=2.0 \quad 10^{-2}$ M.: half-life $\left(t_{1: 2}\right)$ is in parentheses. ${ }^{t}$ Ref. $6 .{ }^{c}$ Ref.

7. "Ref. 9. "Ref. 11 : measured in 0.3 $\mathrm{M} \mathrm{HNO}_{3}$. cavity size of 1a-1d. The wavelength of the $d-d$ band for each conplex measured in acetonitrile or water is observed at longer wavelength than that in nitromethane. indicating the coordination of the solvent molecule(s).

The copper(II) complexes of 1a -1d are deconposed in acidic aqueous solutions. The pseudo first-order rate constants $(k)$ for the decomposition reaction of the complexes $\left(2 \times 10^{.3}\right.$ M) measured in $0.3 \mathrm{M} \mathrm{HClO}_{4}$ aqueous solution at $20{ }^{\circ} \mathrm{C}$ are listed in Table 2, along with those reported for the complexes of 3.4 , and $8 .^{6.11}$ Table 2 shows that the decomposition rates of the complexes of 1a-1d are distinctly slower than those of $[\mathrm{Cu}(3)]\left(\mathrm{ClO}_{4}\right)$. $[\mathrm{Cu}(4)]\left(\mathrm{ClO}_{4}\right)$, and $[\mathrm{Cu}(8)]\left(\mathrm{ClO}_{4}\right)$ \& under similar experimental conditions. This is probably associated with the relatively strong $\mathrm{Cu}-\mathrm{N}$ interactions of the former complexes. Interestingly, the $k$ value decreases in the order of $[\mathrm{Cu}(\mathbf{1 a})]\left(\mathrm{ClO}_{4}\right)_{2}\left(2.9 \times 10^{-5} \mathrm{~s}^{-1}\right)>[\mathrm{Cu}(\mathbf{1 b})]\left(\mathrm{ClO}_{4}\right)_{2}>[\mathrm{Cu}(\mathbf{1 c})]$ $\left(\mathrm{ClO}_{4}\right)_{2}>[\mathrm{Cu}(1 \mathrm{~d})]\left(\mathrm{ClO}_{4}\right)_{2}\left(2.1 \times 10^{-6} \mathrm{~s}^{-1}\right)$. showing that the decomposition reaction rate of the complexes is strongly influenced by the nature of the $N$-alkyl pendant arm. As described above. the ligand field strength of the copper(II) complexes of 1a-1d is nearly independent on the nature of the $N$-alkyl group. The factors affecting the decomposition rate of the complexes are not clearly understood at this point. However. the present result supports the suggestion that one of the most important factors affecting the decomposition reaction may be the "B-strain" of the tertiary amino group involving the $\mathrm{X}$-alkyl group. ${ }^{13}$ According to the "B-strain", the replacement of the $\mathrm{N}$-methyl group in $[\mathrm{Cu}(\mathbf{1 a})]\left(\mathrm{ClO}_{4}\right)_{2}$, with a bulkier $N$-alkyl group enlarges the $\mathrm{C}-\mathrm{N}-\mathrm{C}$ bond angles and eventually weakens the proton affinity of the amino group. It is also expected that the proton affinity of the coordinated anino groups at the six-membered chelate ring involving the $\mathrm{N}$-benzyl group in $[\mathrm{Cu}(\mathbf{1 d})]\left(\mathrm{ClO}_{4}\right)_{2}$ is weaker than that involving $N$-nethyl group in $[\mathrm{Cu}(1 \mathrm{a})]\left(\mathrm{ClO}_{4}\right)$ ) because of the larger ring size caused by the severer B-strain.

\section{Summay}

This study shows that the copper(II) complexes of 15-membered hexaaza macrobicycles (1a - 1d) with one $\mathrm{K}$-alkyl pendant arm cau be prepared in high yield by the one-pot metal-template condensation of three different amines and formaldehyde. The macrobicyclic conplexes are much more inert against decomposition in concentrated $\mathrm{HClO}_{4}$ solution than $[\mathrm{Cu}(4)]\left(\mathrm{ClO}_{4}\right)_{2}$ 
and $[\mathrm{Cu}(8)]\left(\mathrm{ClO}_{4}\right)_{2}$. This work clearly shows that the decomposition reaction of the copper (II) complexes with a 5-6-6-6 chelate ring sequence is strongly influenced by the steric factors of the $N$-alkyl group. even though the alkyl group is attached to the uncoordinated nitrogen atom.

Acknow ledgments. This work was supported in part by the Research Grant of Daegu University:

\section{References}

1. (a) Yan, C. G.; Song, X. K.; Wang, Q. F.; Sun, J.; Siemeling, U.; Bruhn, C. Chent. Conmm, 2008, 1440 and references cited therein: (b) Ohta, Y.; Oishi, S: Fujii, N.: Ohn1o, H. Chem. Commun. 2008, 835.

2. (a) Comba, P.; Kerscher, M.; Lampeka, Y. D.: Lotzbeyer, L.; Pritzkow, H.: Tsumbal, L. Inorg. Chem 2003, 42, 3387; (b) Walker, G. W.; Geue, R.; Haller, K. T.: Rae, A. D.; Sargeson, A. M. J. Chem. Soc., Dalton Trans. 2003. 279

3. (a) Kang, S.-G.: Lee, Y. H.; Jeong, J. H. horg. Chem Commm. 2007, 10, 1429: (b) Kang, S.-G.: Nam, K.; Kim, S.-D. Bult. Koman Chem. Soc. 2004, 25, 1973; (c) Kang. S.-G.: Rvul, K.; Jung, S.-K.; Kim, J. Inorg. Chim. Acta 1999, 293, 140.
4. (a) Harrowfield, T.; Kim, Y.; Lee, Y. H.; Thuery, P. Em J. Inoig Chem. 2003, 2913, (b) Robertson, M. I.: De Iuliis, G. N.: Meader. M.: Lawrance. G. A. Inolg. Chim. Acta 2004, 357. 557: (c) Salavati-Niasari, M.; Davar, F. Inoig. Chem. Commun. 2006, 9 . 175: (d) Anguls, P. M.; Elliott. A. I.: Sargeson. A. M.: Wills. A. C. J. Chem. Soc., Dalton Trans. 2000, 2933.

5. (a) Suh, M. P.; Shin, W.: Kang, S.-G.: Lah, M. S.; Chung, T.-M. Inong. Chem 1989, 28, 1602, (b) Suh, M. P.; Kang. S.-G.; Chung. T.-M. Bull. Korean Chem. Soc. 1990, 11, 206.

6. Kang, S.-G.; Lee, Y. H.; Teong, T. H. Bull. Korean Chem. Soc. 2008, 29, 1273

7. Kang, S.-G.; Nam, K.; Kweon, J. K.; Jung, S.-K.; Lee, U. Bull. Kowan Chem. Soc 2006, 27, 577.

8. (a) Suh, M. P.; Choi, J.; Kang, S.-G.; Shin, W. Mnorg. Chem. $1989,28,1763$; (b) Kang, S.-G.; Song, J.; Teong, T. H. horg. Chim. Acta 2004, 357,605

9. Kang, S.-G.: Jung, S.-K.; Kweon, I. K. Bull Kowan Chem. Soc. 1990, 11,431

10. Suh, M. P.; Kang, S.-G. Inolg. Chem. 1988, 27,2544

11. Lan, W.-T.; Chung. C.-S. J. Chem. Soc., Dalton Trans. 1994, 191.

12. (a) Micheloni, M.: Paoletti, P.: Poggi, A. J. Chem. Soc., Dalton Trans. 1982.61. (b) Busch. D. H. Acc. Chem. Res. 1978. 11.392.

13. Huheey, J. E.; Keiter, E. A.; Keiter, R. L. Inolganic Chemism: Principles of Snicture and Reactivity. $4^{\mathrm{dh}} \mathrm{Ed}$. HarperCollins College Publishers: New York, 1993; pp 341-342. 